\title{
Analysis Of Financial And Income Disparity Between Rural-Urban Areas In Indonesia
}

\author{
By \\ Yuni Andari \\ Regionall Economic Development Study Program Departement of Economics and Business of \\ Vocational College Gadjah Mada University \\ Corresponding Author: yuni.andari@ugm.ac.id
}

Submission: Oktober 30 2019, Accepted: Februari 192020

\begin{abstract}
The purpose of this study is to analyze the factors that affect income disparity between rural-urban areas in Indonesia and to analyze the effect of financial development on economic inequality. The research method used is a quantitative descriptive analysis using multiple linear regression of panel data during the period of 2014-2017. The dependent variable in this study is the difference in income between rural and urban using differences in the amount of rural and urban expenditure as a proxy. The independent variables consist of financial depth scale with total bank assets as a proxy, financial activity withthe amount of agricultural credit as a proxy, and financial efficiency with the ratio of loan to deposit as a proxy. Other control variables are also analyzed including per capita income, government spending, level of education and trade openness. The results of the study showed that the effect of total bank assets on income disparity between rural and urban areas was positive and significant, while the effect of agricultural credit and the ratio between credit to bank deposits did not significantly influence income disparity between rural and urban areas. Government spending, per capita income and education have a positive and significant effect on income disparity between rural and urban areas. Meanwhile, net export as a proxy of regional economic openness data does not significantly influence income disparity. Based on the results of the study, the policy implications that can be recommended to reduce income inequality between rural-urban areas are through increasing the scale of banking finance, increasing government spending on rural areas, increasing the education of rural communities and increasing income per capita.
\end{abstract}

Keywords: Financial and Income Disparities, Panel Data, Multiple Linear Regression.

\section{ABSTRAK}

Tujuan dari penelitian ini adalah untuk menganalisis faktor-faktor yang mempengaruhi perbedaan pendapatan antara desa-kota di Indonesia dan untuk menganalisis pengaruh perkembangan keuangan terhadap ketimpangan ekonomi. Metode penelitian yang digunakan adalah analisis deskriptif kuantitatif dengan menggunakan regresi linier berganda dari data panel. Variabel dependen dalam penelitian ini adalah perbedaan pendapatan antara pedesaan dan perkotaan yang diproksi dengan perbedaan 
Analysis Of Financial And Income Disparity.... (Andari.)

pengeluaran penduduk pedesaan dan perkotaan. Variabel independen terdiri dari data keuangan yang terdiri dari variabel skala kedalaman keuangan yang proksi dengan data total aset bank, variabel aktivitas keuangan yang proksi dengan data jumlah kredit pertanian dan variabel efisiensi keuangan yang proksi dengan data pada rasio jumlah pinjaman terhadap deposito. Variabel lain yang dianggap mempengaruhi disparitas pendapatan adalah pendapatan per kapita, pengeluaran pemerintah, tingkat pendidikan, dan keterbukaan perdagangan. Hasil penelitian menunjukkan bahwa pengaruh total aset bank terhadap disparitas pendapatan antara daerah pedesaan dan perkotaan adalah positif dan signifikan, sedangkan pengaruh jumlah kredit sektor pertanian dan rasio antara kredit terhadap deposito bank tidak signifikan mempengaruhi perbedaan pendapatan antara daerah pedesaan dan perkotaan. Pengeluaran pemerintah, pendapatan per kapita, dan pendidikan memiliki pengaruh positif dan signifikan terhadap perbedaan pendapatan antara daerah pedesaan dan perkotaan. Sementara itu, keterbukaan ekonomi regional yang diwakili oleh data ekspor neto tidak secara signifikan mempengaruhi disparitas pendapatan. Berdasarkan hasil penelitian, implikasi kebijakan yang dapat direkomendasikan untuk mengurangi ketimpangan pendapatan antara desa-kota adalah melalui peningkatan skala keuangan perbankan, peningkatan pengeluaran pemerintah untuk daerah pedesaan, peningkatan pendidikan masyarakat pedesaan dan peningkatan pendapatan per kapita.

Kata kunci: Kesenjangan Keuangan dan Penghasilan, Data Panel, Regresi Linier Berganda.

\section{INTRODUCTION}

One of the main problems of income inequality in Indonesia is that there is a significant disparity in income between the average per capita income of rural and urban residents. During the period of 2007 to 2018, the income of urban residents was 1.7 times higher than the average income of rural residents. High income inequalities may threaten the sustainability of a country's development, thereforethere should be needed a government policy that can integrate development between rural and urban in order to achieve an ideal condition.

According to Buhaerah (2017) the issue of economic disparity between regions and countries and between income groups within one country has been in the spotlight in the last two decades. Inequality can boost the performance of a country's economic growth. On the other hand, however, inequality tends to damagethe process of accumulation of physical capital, human resource development and sustainable economic growth. In fact, in some cases, inequality has proven to have triggered political instability leading to economic volatility which makes the economic situation increasingly difficult to predict over time.

Table 1 Ratio of Income Comparison between Rural and Urban in Indonesia for thePeriod 2007 - 2018

\begin{tabular}{|l|r|r|r|r|r|r|r|r|r|r|r|r|}
\hline \multirow{2}{*}{\multicolumn{1}{|c|}{ Province }} & \multicolumn{8}{|c|}{ Rural and Urban Comparison } \\
\cline { 2 - 15 } & $\mathbf{2 0 0 7}$ & $\mathbf{2 0 0 8}$ & $\mathbf{2 0 0 9}$ & $\mathbf{2 0 1 0}$ & $\mathbf{2 0 1 1}$ & $\mathbf{2 0 1 2}$ & $\mathbf{2 0 1 3}$ & $\mathbf{2 0 1 4}$ & $\mathbf{2 0 1 5}$ & $\mathbf{2 0 1 6}$ & $\mathbf{2 0 1 7}$ & $\mathbf{2 0 1 8}$ \\
\hline Aceh & 1.47 & 1.53 & 1.55 & 1.56 & 1.59 & 1.66 & 1.83 & 1.73 & 1.52 & 1.62 & 1.52 & 1.52 \\
\hline $\begin{array}{l}\text { North } \\
\text { Sumatera }\end{array}$ & 1.54 & 1.50 & 1.54 & 1.55 & 1.29 & 1.24 & 1.30 & 1.32 & 1.27 & 1.31 & 1.36 & 1.32 \\
\hline West Sumatera & 1.64 & 1.50 & 1.50 & 1.46 & 1.46 & 1.45 & 1.55 & 1.52 & 1.42 & 1.42 & 1.40 & 1.40 \\
\hline Riau & 1.52 & 1.44 & 1.34 & 1.51 & 1.44 & 1.59 & 1.58 & 1.61 & 1.34 & 1.38 & 1.31 & 1.32 \\
\hline Jambi & 1.53 & 1.27 & 1.35 & 1.31 & 1.32 & 1.40 & 1.44 & 1.41 & 1.34 & 1.44 & 1.49 & 1.35 \\
\hline South & 1.40 & 1.36 & 1.49 & 1.43 & 1.26 & 1.61 & 1.60 & 1.79 & 1.51 & 1.54 & 1.49 & 1.45 \\
\hline
\end{tabular}




\begin{tabular}{|c|c|c|c|c|c|c|c|c|c|c|c|c|}
\hline \multicolumn{13}{|l|}{ Sumatera } \\
\hline Bengkulu & 1.71 & 1.32 & 1.32 & 1.47 & 1.40 & 1.41 & 1.57 & 1.51 & 1.36 & 1.59 & 1.46 & 1.47 \\
\hline Lampung & 2.20 & 1.82 & 1.71 & 1.69 & 1.52 & 1.59 & 1.76 & 1.68 & 1.51 & 1.50 & 1.52 & 1.44 \\
\hline $\begin{array}{l}\text { Bangka } \\
\text { Belitung Islands }\end{array}$ & 1.04 & 1.11 & 1.16 & 1.34 & 1.11 & 1.25 & 1.36 & 1.26 & 1.20 & 1.27 & 1.41 & 1.31 \\
\hline Riau Islands & 1.59 & 1.61 & 1.42 & 1.45 & 1.41 & 1.44 & 1.56 & 1.64 & 1.62 & 1.61 & 1.65 & 1.52 \\
\hline \multicolumn{13}{|l|}{ DKI Jakarta } \\
\hline West Java & 1.73 & 1.71 & 1.63 & 1.56 & 1.69 & 1.78 & 1.84 & 1.63 & 1.55 & 1.60 & 1.51 & 1.51 \\
\hline Central Java & 1.51 & 1.51 & 1.42 & 1.41 & 1.39 & 1.51 & 1.49 & 1.34 & 1.38 & 1.41 & 1.30 & 1.31 \\
\hline DI Yogyakarta & 1.75 & 1.76 & 1.73 & 1.77 & 1.49 & 1.60 & 1.69 & 1.63 & 1.74 & 1.70 & 1.72 & 1.75 \\
\hline East Java & 1.65 & 1.65 & 1.60 & 1.58 & 1.68 & 1.65 & 1.61 & 1.51 & 1.60 & 1.59 & 1.58 & 1.56 \\
\hline Banten & 2.19 & 1.89 & 1.88 & 2.05 & 1.88 & 1.74 & 1.81 & 1.75 & 1.81 & 1.81 & 1.84 & 1.77 \\
\hline Bali & 1.56 & 1.46 & 1.54 & 1.53 & 1.69 & 1.63 & 1.65 & 1.68 & 1.42 & 1.39 & 1.62 & 1.52 \\
\hline $\begin{array}{l}\text { West Nusa } \\
\text { Tenggara }\end{array}$ & 1.44 & 1.39 & 1.37 & 1.48 & 1.31 & 1.37 & 1.33 & 1.43 & 1.25 & 1.30 & 1.33 & 1.27 \\
\hline $\begin{array}{l}\text { East Nusa } \\
\text { Tenggara }\end{array}$ & 2.40 & 2.18 & 2.10 & 1.93 & 2.07 & 2.12 & 2.30 & 2.26 & 1.95 & 1.99 & 1.92 & 1.93 \\
\hline $\begin{array}{l}\text { West } \\
\text { Kalimantan }\end{array}$ & 1.51 & 1.44 & 1.49 & 1.78 & 1.66 & 1.75 & 1.81 & 1.85 & 1.45 & 1.50 & 1.58 & 1.61 \\
\hline $\begin{array}{l}\text { Central } \\
\text { Kalimantan }\end{array}$ & 1.50 & 1.44 & 1.49 & 1.30 & 1.38 & 1.45 & 1.49 & 1.37 & 1.24 & 1.30 & 1.32 & 1.28 \\
\hline $\begin{array}{l}\text { South } \\
\text { Kalimantan }\end{array}$ & 1.75 & 1.69 & 1.52 & 1.55 & 1.51 & 1.61 & 1.68 & 1.53 & 1.49 & 1.37 & 1.52 & 1.50 \\
\hline $\begin{array}{l}\text { East } \\
\text { Kalimantan }\end{array}$ & 1.66 & 1.79 & 2.11 & 1.89 & 1.63 & 1.69 & 1.80 & 1.67 & 1.34 & 1.35 & 1.47 & 1.41 \\
\hline $\begin{array}{l}\text { North } \\
\text { Kalimantan }\end{array}$ & & & & & & & & & 1.29 & 1.32 & 1.51 & 1.23 \\
\hline North Sulawe & 1.48 & 1.23 & 1.13 & 37 & 1.42 & 1.54 & 1.56 & 1.51 & 1.43 & 1.46 & 1.49 & 1.51 \\
\hline $\begin{array}{l}\text { Central } \\
\text { Sulawesi }\end{array}$ & 1.55 & 1.61 & 1.69 & 1.71 & 1.57 & 1.78 & 1.86 & 1.88 & 1.60 & 1.62 & 1.66 & 1.55 \\
\hline South Sulawesi & 2.05 & 2.00 & 2.26 & 1.95 & 1.70 & 1.67 & 1.77 & 1.75 & 1.72 & 1.84 & 1.76 & 1.61 \\
\hline $\begin{array}{l}\text { Southeast } \\
\text { Sulawesi }\end{array}$ & 1.87 & 1.97 & 2.33 & 2.31 & 1.96 & 1.80 & 1.86 & 1.86 & 1.56 & 1.60 & 1.58 & 1.59 \\
\hline Gorontalo & 2.03 & 1.74 & 1.55 & 1.49 & 1.56 & 1.46 & 1.49 & 1.52 & 1.81 & 1.62 & 1.67 & 1.56 \\
\hline West Sulawesi & 1.11 & 1.21 & 1.21 & 1.48 & 1.45 & 1.50 & 1.39 & 1.30 & 1.26 & 1.32 & 1.40 & 1.43 \\
\hline Maluku & 1.97 & 1.87 & 1.73 & 1.44 & 1.60 & 1.72 & 1.79 & 1.67 & 1.50 & 1.61 & 1.55 & 1.82 \\
\hline North Maluku & 1.74 & 1.86 & 2.09 & 1.99 & 1.77 & 1.84 & 1.95 & 1.79 & 1.35 & 1.53 & 1.71 & 1.77 \\
\hline West Papua & 1.97 & 1.81 & 1.96 & 2.12 & 1.78 & 2.12 & 2.03 & 1.95 & 1.44 & 1.58 & 1.57 & 1.41 \\
\hline Papua & 2.54 & 2.31 & 2.28 & 1.94 & 2.26 & 2.32 & 2.49 & 2.47 & 2.26 & 1.85 & 1.79 & 1.71 \\
\hline Indonesia & 1.80 & 1.75 & 1.72 & 1.69 & 1.70 & 1.75 & 1.79 & 1.71 & 1.63 & 1.64 & 1.62 & 1.58 \\
\hline
\end{tabular}

Source: BPS(2014-2017) processed

Development can be broadly defined as the transformation of society from traditional economic societies into societies with more modern economies. The transformation is divided into agriculture sector transformation, population transformation, institutional transformation and structural transformation. According to Zhanga (2012), economic development is a broadly defined as process, which is not only shown by increased income levels but also by other variables such as financial development based on scale, bank loans to farmers, financial sector efficiency, urbanization, trade openness, education, tertiary industry and government fiscal expenditure.

The financial system plays a very important role in the economy along with its function to channel funds from parties who have excess funds to those who need funds. The financial system will contribute to economic growth and reduce poverty if it goes well. If the financial system does not work well, the economy will become inefficient and the expected economic growth will not work 
properly. The financial crisis occurred because of the malfunctioning of the financial system so that the crisis caused losses to the economy and welfare of the people. The 1998 crisis and the 2008 global financial crisis are examples of how the the financial crisis has affected the Indonesian economy. Various studies have shown that a good financial system can encourage faster economic growth. The problem experienced by developing countries in general is that a good financial system has not yet been developed.

Clarke et al. (2006) stated that financial development can increase growth and reduce inequality. Kalipioni (2010) empirically measured the impact of the availability of financial services on income inequality. The resultsshowed that barriers to access to banks significantly increase income inequality. According to Marsoessetiawan (2016), financial development plays an important role in the development of a nation. One of the reasons why developing countries experience low economic growth and is associated with poverty and income inequality is the financial system that has not been well developed. Zhanga (2012) examined the relationship between differences in urban-rural income and development in China during the 1978-2006 period using panel data from 30 provinces. The results showed that there was an inverse $U$ relationship between the urban-rural income gap and GDP per capita. Financial development through bank lending in general has enlarged the urbanrural income gap. Lee's research (2012) also showed that economic inequality has a negative effect on national economic growth. In addition, the financial gap is exogenous, indicating that the financial gap is not influenced by economic disparity or national economic growth.

According to Nasution (2012) the ratio of credit to GDP in Indonesia is the lowest in Asia, at 31.7 percent. The ratio is much lower than Malaysia (115.9 percent), Vietnam (111.6 percent), and Thailand (131.9 percent). The low credit ratio reflects that the role of banks for Indonesia's economic growth has not been maximized. The following table presents the percentage of loans disbursed by banks by sector in Indonesia in 2010-2016.

Table 3. Percentage of Credit disbursed by Indonesian Banking Industry by Economic Sector 20102016

\begin{tabular}{|c|c|c|c|c|c|c|c|}
\hline Economic Sector & 2010 & 2011 & 2012 & 2013 & 2014 & 2015 & 2016 \\
\hline Agriculture & 5.2 & 5.2 & 5.5 & 5.6 & 6.0 & 6.5 & 6.8 \\
\hline Industry & 15.4 & 15.4 & 16.2 & 17.3 & 17.7 & 18.3 & 17.4 \\
\hline Mining & 3.4 & 3.8 & 3.7 & 3.8 & 3.8 & 3.1 & 2.7 \\
\hline Trading & 19.4 & 18.6 & 20.3 & 21.5 & 21.7 & 21.9 & 21.3 \\
\hline Services & 25.7 & 26.0 & 6.1 & 4.8 & 3.8 & 3.4 & 3.6 \\
\hline Others & 30.9 & 30.8 & 48.2 & 47.1 & 47.1 & 46.8 & 48.3 \\
\hline Total & 100.0 & 100.0 & 100.0 & 100.0 & 100.0 & 100.0 & 100.0 \\
\hline
\end{tabular}

Based on the table 3 it can be seen that the credit allocation for the agricultural sector is relatively small with an average of $5 \%$ while for the industrial sector $17 \%$ and trade $21 \%$.

Marsossetiawan (2016) investigates the effect of financial development on regional income disparities in Indonesia, which is proxy by the Gini Index of each province. The results showed that the ratio of private sector credit to GDP as a proxy for financial depthhad a negative and significant influence on regional income disparities in Indonesia, the number of bank offices per $1,000 \mathrm{~km}^{2}$ as a proxy for financial access did not have a significant effect on regional income gaps in Indonesia. The variable GDP per capita and the inflation rate have a positive and significant influence on regional income disparities in Indonesia. The ratio of the total export-import ratio to the GRDP has no significant effect and the government consumption variable per capita has a negative and significant effect on the regional income disparities in Indonesia. 
Meanwhile the results of Jauch's research (2016) reject the theoretical model that predicts the negative impact of financial development on income inequality. The results of his research showed that financial development increased income inequality.

The uneven spatial distribution of economic and financial activities in Indonesia has long been a concern of researchers and policy makers. While most of the previous research focused on regional disparity as measured using provincial data, this study tried to investigate intra-provincial disparities that reflect dispersion among rural-urban areas within a particular province. This study analyzes the relationship between economic disparity and financial disparity using provincial-level data from 2010 to 2017, and examine the effects of intra-provincial disparities on the economic growth of the studied provinces.

Based on this background, the reason why the researchersare interested in analyzing the effect of financial development on income disparity in rural and urban societies is that there are inconclusive results of previous studies on the impact of financial development on income disparity. In Indonesia there is a lack of research on the relationship between financial development and income inequality. Previous studies also generally used a characteristic of financial development such as the ratio of credit of the private sector to GDP, which measures the size of the banking and nonbanking sectors that contribute to the economy, even though according to the World Bank (2013), financial development measures do not only consist of financial depth it is the size of the banking and non-banking sectors that contribute to the economy but also judged by the ease of individuals or companies using financial services (financial access), and the efficiency of financial institutions in providing financial services (financial efficiency), and the stability of financial institutions (financial stability).The objectives of the study are:

1. To analyze the effect of financial sector development on income disparities between rural and urban areas

2. To analyze the effect of government expenditures on income disparities between rural and urban areas

3. To analyze the effect of average income per capita on income disparities between rural and urban areas

4. To analyze the effect of trading openness and education on the income disparities between rural and urban areas

\section{METHODS}

The datum used was secondary data. Secondary data were obtained from BPS(Central Bureau of Statistics) and OJK(Financial Services Authority). The data used were time series data from 2014-2017 and cross section data of 32 (thirty-two)provinces in Indonesia. This research used descriptive and quantitative analysis. Descriptive analysis is based on the study of literature through articles, books and research results relating to variables that affect disparities of financial dan income. The quantitative tool used in this study was multiple linear regression using panel data.

The research model used in this study refers to the study of Zhanga (2012) which states that there are several factors that influence income disparities between rural-urbanareas (ID), namely:

1. Composite financial variables $(F)$

2. Government Expenditure $(G)$

3. Output per Capita (Y)

4. Several explanatory variables $(X)$ also affect development, such as level of education and trade openness

$$
I D=f(F, G, Y, X)
$$

The total differentiation of equation (1) results in:

$$
d I D=\frac{\partial f}{\partial F} d F+\frac{\partial f}{\partial G} d G+\frac{\partial f}{\partial Y} d Y+\frac{\partial f}{\partial X} d X
$$


Composite financial variables consist of financial scale, types of financial activities and financial sector efficiency. Zhang (2012) assumes that financial development is represented by the total financial assets represented by FA (Financial Assets) namely the scale or depth of finance. For banking activities, symbolized by the FSA, data proxy is used in the form of the amount of agriculture sector loans, as well as amount of loan created from bank deposit units represent the efficiency of the financial sector, as indicated by FSE.

$F=F($ FA, FSA, FSE).

In this study, the level of financial development does not include capital market variables because Indonesia's financial structure is mainly dominated by banks and capital market development is relatively not too rapidly developing. Another reason is the difficulty of finding capital market data for the provincial level. The total differentiation from equation (3) results in:

$d F=\frac{\partial F}{\partial F A} d F A+\frac{\partial F}{\partial F S A} d F S A+\frac{\partial F}{\partial F S E} d F S E$

Substitution from equation (4) to equation (2) becomes:

$d I D=\frac{\partial F}{\partial F A} d F A+\frac{\partial F}{\partial F S A} d F S A+\frac{\partial F}{\partial F S E} d F S E+\frac{\partial f}{\partial G} d G+\frac{\partial f}{\partial A G D P} d A G D P+\frac{\partial f}{\partial E D U} d E D U+$ $\frac{\partial f}{\partial N E} d N E$.

Based on equation (5), the basic model of this study is assumed as follows:

$\operatorname{Ln}\left(I D_{i t}\right)=a+b_{1} L n F A_{i t}+b_{2} F S A_{i t}+b_{3} L n F S E_{i t}+b_{4} L n G_{i t}+b_{5} L n A G D P_{i t}+b_{6} L n E D U_{i t}+b_{7} \operatorname{LnNE}-$

$\boldsymbol{e}_{i t}$

Where:

$\begin{array}{ll}\text { ID } & : \text { Income Disparities } \\ \text { FA } & : \text { Total Financial Asset } \\ \text { FSA } & : \text { Financial Sector Activities } \\ \text { FSE } & : \text { Financial Sector Efficiency } \\ \text { G } & : \text { Government Expenditures } \\ \text { AGDP } & : \text { Average GDP per capita } \\ \text { EDU } & : \text { Level of Education } \\ \text { NE } & : \text { Net Export } \\ \mathrm{a} & : \text { Constant } \\ \mathrm{b}_{1}, \mathrm{~b}_{2}, \mathrm{~b}_{3}, \mathrm{~b}_{4}, \mathrm{~b}_{5}, \mathrm{~b}_{6}, \mathrm{~b}_{7} & : \text { Coefficient } \\ \mathrm{i} & : \text { Cross Section } \\ \mathrm{t} & : \text { Time Series } \\ \mathrm{e} & : \text { error term }\end{array}$

\section{RESULTS AND DISCUSSION}

The average income disparity which is proxy by monthly expenditure per capita between rural and urban in Indonesia during the 2014-2015 period is Rp393.605.2. Provinces that have disparity values above the national average are Aceh, Riau Islands, DIY, Banten, Bali, East Nusa Tenggara, West Kalimantan, South Kalimantan, East Kalimantan, Central Sulawesi, South Sulawesi, Gorontalo, North Maluku, Papua and West Papua. The highest disparity in average monthly expenditure per capita in urban and rural areas in 2014-2017 was observed in Papua Province with an average value of Rp721.697.91. Despite having the highest disparity value, the disparity growth rate in Papua Province on average decreased by $-1.3 \%$ during the analysis period. the province of West Sulawesi had the lowest average expenditure per capita per month in urban and rural areas, which was Rp.192.278.91. However,the average monthly per capita expenditure in urban and rural areas in West Sulawesi 
Province experiences an increasing trend every year with an average growth rate of $23.8 \%$. the highest growth rate of income disparity between rural and urban occurred in the province of Bangka Belitung with a disparity growth rate of $28.57 \%$, while the lowest disparity growth rate on average during the 2014-2017 period occurred in Papua Province Riau, which is $-10.05 \%$.

Graph 1. Average Income Disparity Between Rural-Urban Area In Indonesia 2014-2017 (Rp/Cap/Month)

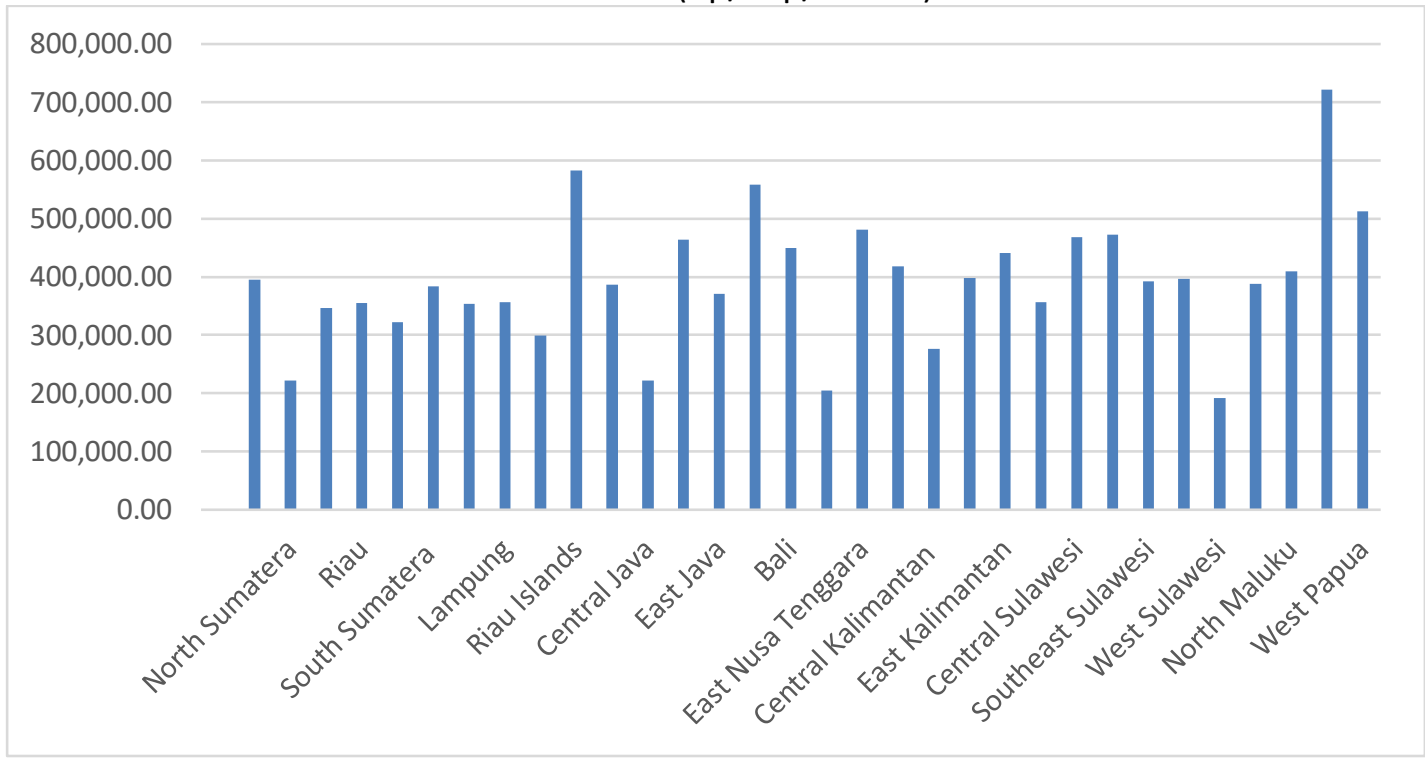

Source: BPS (2014-2017) processed

During 2014-2017, the average total national banking assets reached Rp98,776,536.77 million with an average growth of $9 \%$ per year. The East Java Province had the highest average total banking assets compared to the other provinces, which was Rp559,000,750 average value and with an average growth of $8.95 \%$ per year. The Provinces of West Java, Central Java, North Sumatra, Banten and Bali are the provinces with the next largest assets after East Java. West Sulawesi Province is the province with the lowest banking assets, reaching an average value of $R p \quad 6,216,581$ million, but with the highest asset growth rate in Indonesia, which is an average of $18.75 \%$ per year. North Maluku and Gorontalo provinces are the second and third lowest provinces with banking assets reaching an average value of Rp8,489,268 million and Rp9,883,109 million but with an average increase in assets each year of $11.79 \%$ and $11.09 \%$ respectively. The province of Central Kalimantan is the province with the lowest asset growth rate during the analysis, which averaged $-6.19 \%$ per year. 
Graph 2.Average Income Disparity Growth Rate in Indonesia Period 2014-2017 (\%)

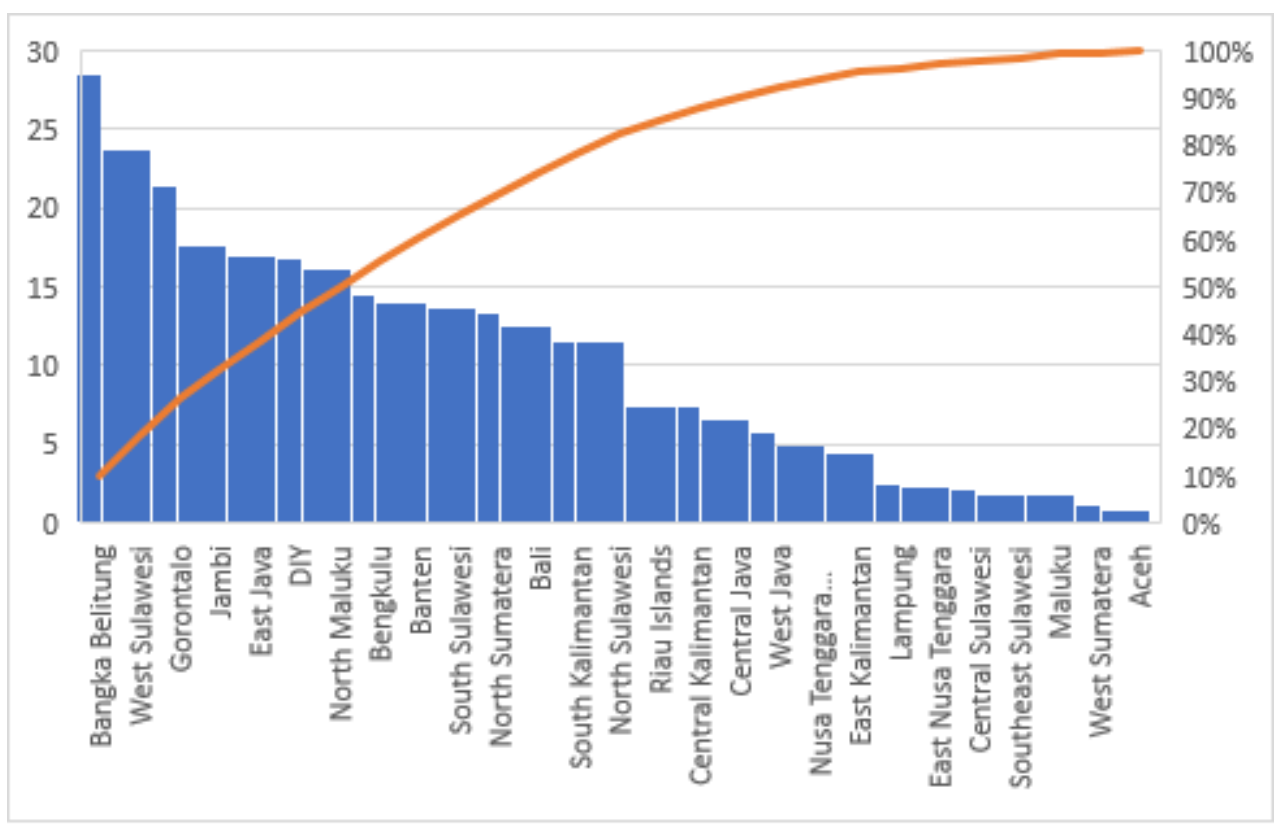

Source: BPS (2014-2017) processed

During the 2014-2017 period, the average agricultural credit reached Rp47,234.17 million and had an average growth of $6.08 \%$ per year. North Sumatra Province has the highest average agricultural credit compared to the other provinces, which is Rp373,229.80 million the average value each year but has an average decline of $9.79 \%$ per year. The provinces of Riau, South Sumatra, East Java, West Kalimantan and Lampung respectively are the provinces with the next largest agricultural credit after North Sumatra province. West Papuais the province with the lowest agricultural credit, reaching IDR93.23 million with an average decline in agricultural credits of $40.02 \%$ per year. North Maluku and Maluku Provinces are the second and third lowest provinces with agricultural credit reaching Rp230.18 million and Rp869.32 rupiah with an average annual decline in agricultural credits of $19.09 \%$ and $22.28 \%$. Papua is the province with the lowest average decline in agricultural credit during the analysis, reaching an average of $40.02 \%$ per year.

The total credit ratio to deposit has the highest average of $104.94 \%$ with an average growth of $0.93 \%$ per year. West Sulawesi Province has the highest average credit to savings ratio compared to other provinces, which is $221.60 \%$ average value but the average decrease of $2.27 \%$ per year. The provinces of Maluku, Bengkulu, Central Sulawesi, South Sulawesi and East Nusa Tenggara are the provinces with the next largest credits to savings ratio after West Sulawesi. Meanwhile, East Java Province was the province with the lowest credit to savings ratio, reaching a value of $60.37 \%$ with a decline in the ratio of credit to savings by $1.09 \%$ per year. The provinces of West Papua and Bangka Belitung are the second and third lowest provinces with a ratio of credit to savings reaching a value of $62.29 \%$ and $65.48 \%$ with an average increase in the ratio of credit to savings each year by $2.11 \%$ and $-2.04 \% \%$. Aceh Province was the province with the lowest growth rate of credit to savings ratio during the analysis, which was $-2.94 \%$ per year, which means there is a decrease of $2.94 \%$ per year.

The average ratio of government expenditure to GDP reached $4.44 \%$ with an average growth of $4.90 \%$ per year. Aceh Province has the highest average ratio of government expenditure to GDP compared to the other provinces, which is $11.42 \%$ with a growth rate of $2.19 \%$ per year. The provinces of Papua, West Papua, Maluku, Bengkulu and West Kalimantan are the provinces with the highest government expenditure to GDP ratio next to Aceh province. Meanwhile Banten Province is the province with the lowest ratio of government expenditure to GDP, reaching $1.87 \%$ with a growth rate of the ratio of government expenditure to GDP of $2.71 \%$ per year. Riau Islands and North Sulawesi Provinces are the second and third lowest provinces with a ratio of government 
expenditure to GDP reaching an average value of $1.96 \%$ and $2.14 \%$ with a decrease in the average ratio of government expenditure to GDP of Riau Islands annually by 3, $26 \%$ while the Province of North Sulawesi has an average growth of the ratio of government expenditure to GDP of 5.55\%. East Kalimantan Province is the province with the lowest growth rate of government expenditure to GDP ratio during the analysis, reaching $-13.20 \%$ per year, which means the rate of decline in the ratio of government expenditure to GDP of East Kalimantan Province annually by $13.20 \%$.

During the 2014-2017 period the average of GDP per capita reached Rp 34,168.61 million with an average growth of $3.76 \%$ per year. East Kalimantan Province has the highest average GDP per capita compared to the other provinces in the amount of IDR 128,825 million with fluctuating values each year but has the lowest average growth of $-1.63 \%$ per year which means it has an average a decrease of $1.63 \%$ per year. Riau Islands Province, Riau, West Papua, Papua and Jambi are successively the provinces with the next highest average GDP per capita after East Kalimantan. Meanwhile East Nusa Tenggara Province is the province with the lowest average GDP per capita, reaching an average value of Rp11,290.58 million with a growth rate of 3.36\% per year. Maluku and North Maluku provinces are the second and third lowest provinces with an average GDP per capita reaching Rp15,055.89 million and Rp17,943.39 million with an average increase in GDP per capita per year of $3.89 \%$ and $4.40 \%$. Riau Province is the province with the lowestaverage GDP growth rate per capita during the analysis, which is an average of $-0.75 \%$ per year, which means that the average GDP growth rate per capita in Riau Province continues to decline every year by 0,75 .

The average total dropout rate is 7,772.51 with an average decrease of $23.93 \%$ per year which means that the dropout rate is decreasing. West Java Province has the highest average dropout rate compared to the other provinces in the amount of $47,097.75$ average value but has an average decline of $20.47 \%$ per year. The provinces of East Java, Central Java, North Sumatra, South Sulawesi and Banten were the provinces with the next largest dropout rates after West Java. Meanwhile Gorontalo Province was the province with the lowest dropout rate, reaching a value of $1,489.75$ with an average decrease in dropout rate of $25.81 \%$ per year. Bangka Belitung Province and Riau Islands are the second and third lowest provinces with dropout rates reaching 1,490 and $1,499.25$ with an average decrease in dropout rates every year of $10.42 \%$ and $10.46 \%$. East Java Province is the province with the lowest dropout rate during the analysis, which is an average of $9.46 \%$ per year, which means that the dropout rate has decreased by $9.46 \%$ per year.

Net export is the difference between exports and imports that reflects regional openness, with the highest average of 2,607.9 US $\$$ but has an average decline of $0.5 \%$ per year which means that national net exports are decreasing. Central Java Province has the highest net export average compared to the other provinces, which is 32,835 US $\$$ with fluctuating values each year and has an average growth of $5.74 \%$ per year. West Java, Central Sulawesi, South Sulawesi, Riau Islands and Riau Provinces were the provinces with the next largest net exports after Central Java. Meanwhile South Sumatra Province is the province with the lowest net export, reaching a value of -1718 , which means that South Sumatra Province imports more than exports with an average decline of $3.7 \%$ per year. The provinces of Gorontalo and Bangka Belitung were the second and third lowest provinces with net exports reaching values of -28.43 and -4.2 with decreases in average net exports each year of $0.11 \%$ and $6.99 \%$. Aceh Province is the province with the lowest net export growth rate with an average decline of $11.85 \%$ per year.

This study used multiple panel linear regression models with Eviews 9. software assistance. After going through various tests such as the goodness of Fit test of the model, the variable significance test, the equation significance test, heteroscedasticity test, serial correlation test, multicollinearity test and etc., the estimation results are obtained with Fixed Effects models as follows:

\section{$I D_{i t}=-293327,2+0,00083 F A_{i t}+0,224858 F S A_{i t}+138,3396 F S E_{i t}+33361,49 G_{i t}+11,71185$ $A G D P_{i t}+2,371549 E D U_{i t}+0,319078 N E_{i t}+e_{i t}$}


Based on the estimation results, it is obtained that simultaneously total banking assets, the amount of agricultural credit, the ratio of the number of loans to deposits, the ratio of government expenditure to GDP, per capita income, education level and net exports of each province significantly influence the income disparity between rurals and urbans. The capability of the bank's total assets, the amount of agricultural credit, the credit-to-deposit ratio, the ratio of government expenditures to GDP, GDP per capita, education, and net exports to explain income differences between rural and urban areas was $79.13 \%$.

Based on the results of the partial significance test, the results showed that the influence of the total banking asset, the ratio of government expenditure to GDP and GDP per capita to income disparity between rural and urban areas is significant at $\alpha=5 \%$ level. While the education level influences the income disparity between rurals and urbans at a confidence level of $90 \%$. Meanwhile theamount of agricultural credit, the ratio of credit to deposits and net exports did not significantly influence income disparity between rural and urban areas.

The influence of the total banking asseton income disparity between rurals and urbans is positive and significant and the banking asset coefficient is 0,00083 which means that when there is an increase in banking assets of 1 million Rupiah, the disparity will increase by 0,00083 Rupiah ceteris paribus. This shows that the increase in scale or depth of the financial sector which is proxy by the total amount of banking assets has actually worsened income disparity between regions. This is possible because the banking structure in Indonesia tends to be oligopoly, where the majority of large banks are owned by the government with a concentration of their main activities in urban rather than rural area.

The influence of the amount of credit extended to the agricultural sector is positive but not significant. This shows that credit disbursed to the agricultural sector is still relatively low which is only in the range of $5 \%$ of the total credit, this causes agricultural credit does not significantly influence the income of rural societies with the big majority and living in the agricultural sector.

The efficiency of the financial sector which is proxy bythe ratio of loans to the amount of savings has a positive effect on income disparity between rural and urban areasbut has no significant effect. This is possible because the existing banks do not yet have a good level of efficiency, as evidenced by the fact that there are still several provinces that have a credit to savings ratio that exceeds the maximum lending limit of $70 \%-80 \%$. The high ratio of credit to savings in some provinces shows that the source of credit comes from outside the deposits that can be collected by banks. These sources can come from bank loans to other parties or from their equity.

The ratio of government expenditure to GDP has a positive and significant effect on income disparity between rural and urban areas with a coefficient of 33,361.49, which means that when there is an increase in government expenditure to GDP by 1 percent, the income disparity between rural and urban areas will increase by 33,361.49 Rupiah. Provinces with a high ratio of government expenditure to GDP tend to have high expenditure for regional needs so that they can support economic development in their regions, and vice versa, provinces with a low ratio of government expenditure to GDP tend to have low government spending so that their carrying capacity towards the economy in smaller area. This has an impact on the increasing disparity in income between regions. The increase in government expenditure is expected to encourage economic growth through its multiplier effects such as increased consumption and employment. However, this effect is more common in urban areas than in rural areas, so the impact of government expenditure on rural community income is not significant.

The effect of GDP per capita on income disparity between rural and urban areasis positive and significant with a regression coefficient of 11.71185 , which means an increase in GDP per capita of 1 million will increase disparity by 11.71185 Rupiah. This shows that the higher per capita income of the community actually deepens the income disparity between communities, which means that there is uneven distribution of income between regions.

The dropout rate as a proxy of level education has a positive effect on income disparity between rural and urban areas at confidence level of $90 \%$. The education level regression coefficient is 2.371549 , which means an increase in 1 dropout rate will increase income disparity between rural 
and urban by 2.371549 Rupiah. This means that the higher the dropout rate, the higher the disparity in income between rural and urban areas. The high dropout rate tends to occur in rural than in urban areas. The relatively lower income of rural communities, lack of access and opportunities for schools makes higher dropout rates occur in rural areas compared to urban areas. Low levels of education lead to low quality human resources so that opportunities for employment are low and ultimately low income levels.

The value of exports and imports has a positive but not significant effect on income disparities between rural and urban areas. With a coefficient value of 0.319078 which means an increase in the value of exports and imports by 1 million Rupiah, it will increase disparity by 0.319078 Rupiah. This shows that an increase in the export-import of an area will increase income disparity between rural and urban areasif there are regions that have high import-export commodities compared to regions that do not have leading commodities and lack of openness to other regions so that net export is low.

The results of this study are in line with the results of Buhaerah (2017), Clarke (2006), Zhanga (2012), Kalipioni (2010), Marsoesetiawan (2016), Jauch (2016), (Law (2014), Aginta (2018) and Bezemera (201) 2019) which says that there is a relationship between financial development and income inequality, in contrast to the results of Lee's study (2012) which states that financial differences do not affect income differences or economic growth.

Clarke (2006) examines the relationship between financial inequality and income for 83 countries between 1960 and 1995. The results show that, in the long run, inequality decreases when there is greater financial development. Clarke's (2006) research results are consistent with Galor and Zeira (1993) and Banerjee and Newman (1993). Although the results also show that inequality might increase along with the increase in financial sector development. The low level of development of the financial sector, as suggested by Greenwood and Jovanovic (1990), results are not strong. We reject the hypothesis that financial development benefits only the rich. The results show that in addition to increasing growth, financial development also reduces inequality.

Buhaerah (2017) examines the impact of Financial development on income inequality in ASEAN5 countries for the period 1990-2013 using panel data analysis. The results showed that there was a significant relationship between financial indicators and income distribution. Financing indicators such as stock market capitalization and asset returns contribute positively to worsening income inequality. Conversely, domestic private debt securities have a negative effect on this coefficient in ASEAN-5 countries which indicates that an increase in domestic private debt securities will increase the distribution of income in the region.

Law (2014) examines the relationship between financial development and income inequality. The results show that the relationship between financial development and income varies according to the level of institutional quality. Empirical evidence shows that there is an influence of institutional quality threshold in the relationship between financial development and income inequality. Financial development tends to reduce income inequality only after a certain threshold of institutional quality has been reached. Until these conditions, the influence of financial development on income inequality does not exist. This finding shows that institutional quality influences the relationship between financial development and income inequality, which reflects the idea that better quality finance results in a more equal distribution of income.

Aginta's research (2018) aims to compile indicators of financial inclusion in all provinces in Indonesia and analyze the relationship of financial inclusion with income gaps. At the national level, estimation results show that financial inclusion has no significant impact on income inequality. By adding other variables such as GRDP, school length, and trade openness, the estimation model shows variable results. Financial inclusion has a significant impact in reducing income disparities in provinces that are dominated by the manufacturing and mining sectors, not in the agricultural sector.

Bezemera (2019) examined the relationship between financial development and income inequality, with a sample of 40 developed countries during 1990-2013. The results showed that there was a shift in the allocation of bank credit, far from supporting non-financial investment 
company and to finance the real estate market. Bezemera (2019) found that mortgage credit increases income inequality while credit for non-financial businesses reduces inequality. Home prices and the size of the real estate sector affect the impact of mortgage credit on income inequality.

From the empirical results mentioned above, we can identify policy and institutional problems and provide some useful policy implications: first, the Indonesian financial system is dominated by banks, mostly state-owned, has been centered on urban development and large companies, stateowned with the cost of developing rural and competitive small and medium businesses, making it difficult to increase rural productivity to catch up with urban productivity. To reduce this problem, one can suggest curbing in the oligopoly of state-owned companies and encouraging competition between foreign banks, private banks and state-owned banks to increase financial scale and efficiency in using financial resources. Also, one might suggest expanding the scale by turning savings into investment, relaxing government control over financial intermediation, and developing the banking system at different levels to meet different funding requirements. In particular, one might suggest establishing and developing regional small and medium commercial banks, and strengthening financial support for private companies and rural areas. In addition, it helps to reform rural credit corporations that can play an active role in agricultural industrialization and provide various financial services for various groups. Finally, government fiscal policy needs to be more supportive of rural areas, such as village funds, as well as rural infrastructure funding which is urgently needed for irrigation, transportation, communication and health care. The focus of this shift in government spending has indeed been echoed in recent steps to integrate urban and rural development. Improving the quality of public education needs to be improved, such as increasing education funding and funding for educational facilities and infrastructure in rural areas.

\section{CONCLUSION}

This study examines the impact of financial sector development on income disparity between rural areas and provincial level urban areas in Indonesia. In this research, the development of the financial sector is more measured by the number of banking assets, the amount of credit extended to the agricultural sector and the ratio of credit to bank deposits. Although the impact of agricultural credit and the ratio of credit to deposits does not significantly affect income disparity, financial depth measured through total banking assets has a positive and significant effect on income between rural and urban areas. Previous studies have examined the impact of financial development on income disparity at the aggregate or national level, with financial development variables that emphasize the ratio of private sector credit to GDP compared to the amount of credit to the agricultural sector. This study also includes other explanatory variables in the form of government spending, average per capita income, education level and trade openness which are estimated to affect income disparity.

The result showed that partially the influence of financial scale, government expenditure, per capita income and education level on income disparity between rural and urban were positive and significant. Meanwhile the influence of types of financial activities and financial efficiency was not significantly. Net export data as a proxy of regional economic openness did not significantly influence income disparity.

\section{REFERENCES}

Aginta, Harry., Soraya Debby., \& Santosa, Wahyu., (2018). Financial Development and Income Inequality in Indonesia: A Sub-national Level Analysis. Economics and Finance in Indonesia, Vol. 64 No. 2, December 2018: 111-130

Badan Pusat Statistik. (n.d.). Rata- rata PDRB seri 2010 Atas Dasar Harga Konstan Menurut Lapangan Usaha 2010 -2017 (Juta Rupiah). Retrieved Agustus 8, 2019, from https://bps.go.id

Badan Pusat Statistik. (n.d.). Rata-Rata Pengeluaran per Kapita Sebulan di Daerah Perkotaan dan Perdesaan Menurut Provinsi dan Kelompok Barang (rupiah) tahun 2011-2018. Retrieved Agustus 30, 2019, from https://www.bps.go.id 
Badan Pusat Statistik. (2017, December $7^{\text {th }}$ ). Statistik Keuangan Pemerintah Provinsi 2014 - 2017. Retrieved Agustus 8, 2019, from Badan Pusat Statistik: https://www.bps.go.id

Bank Indonesia . (n.d.). Statistik Ekonomi dan Keuangan Daerah (SEKDA). Retrieved Agustus 28, 2019, from https://www.bi.go.id

Banerjee, Abhijit V., and Andrew F. Newman. (1993). Occupational choice and the process of development. Journal of Political Economy 101: 274-98.

Bezemera, Dirk., \& Samarina, Ana., (2019). Debt Shift, Financial Development and Income Inequality. DNB Working Paper. No.646/Agustus 2019. Netherlands: De Nederlandsche Bank NV

Buhaerah, P. (2017). Pengaruh Finansialisasi Terhadap Ketimpangan Pendapatan Di Asean: Analisis Data Panel. Buletin Ekonomi Moneter dan Perbankan, Vol 19, Number 3.

Clarke George R.G, Xu Lixin Colin, Zou Heng-fu. (2006). Finance and Income Inequality: What Do the Data Tell Us?. Southern Economic Journal. 72(3). 578-596

Galor, Oded, and Joseph Zeira. (1993). Income Distribution And Macroeconomics. Review Of Economic Studies 60:35-52.

Jauch, Sebastian., \& Watzka Sebastian. (2016). Financial Development And Income Inequality: A Panel Data Approach. Empir Econ 51:291-314 DOI 10.1007/s00181-015-1008-x

Kalipioni, P., \& Mookerjeea, R., (2010). Availability Of financial Services And Income Inequality: The Evidence From Many Countries. Emerging Market Review, 4 (11), 404-408

Kementerian Pendidikan dan Kebudayaan Republik Indonesia . (n.d.). Ikhtisar Data Pendidikan Tahun 2015/2016. Retrieved September 28, 2019, from http://publikasi.data.kemdikbud.go.id

Kementerian Pendidikan dan Kebudayaan Republik Indonesia. (2017). Statistik Sekolah Dasar (SD) 2016/2017. Retrieved September 28, 2019, from http://publikasi.data.kemdikbud.go.id

Kementerian Pendidikan dan Kebudayaan Republik Indonesia. (2016). Perkembangan Pendidikan Tahun $2009 / 2010$ - 2014/2015. Retrieved September 28, 2019, from http://publikasi.data.kemdikbud.go.id

Kementerian Pendidikan dan Kebudayaan Republik Indonesia. (2017). Ikhtisar Data Pendidikan dan Kebudayaan 2017/2018. Retrieved September 28, 2019, from http://publikasi.data.kemdikbud.go.id

Kementerian Pendidikan dan Kebudayaan Republik Indonesia. (n.d.). Indonesia Educational Statistics In Brief 2014/2015. Retrieved September 28, 2019, from http://publikasi.data.kemdikbud.go.id

Kementerian Pendidikan dan Kebudayaan Republik Indonesia. (2017). Rangkuman Statistik Pendidikan Dasar Dan Menengah 2016/2017. Retrieved September 28, 2019, from http://publikasi.data.kemdikbud.go.id

Kementerian Perdagangan Republik Indonesia. (n.d.). Perkembangan Ekspor NonMigas (Provinsi) Tahun 2014-2019. Retrieved September 28, 2019, from https://www.kemendag.go.id

Kementerian Perdagangan Republik Indonesia. (2014-2019). Perkembangan Impor NonMigas (Provinsi) Periode. Retrieved September 28, 2019, from https://www.kemendag.go.id

Law, Siong Hok., Saini, Azman., \& Tan, Hui Boon (2014). Financial Development and Income Inequality at Different Levels of Institutional Quality. Emerging Market Finance and Trade, 50 (s1), 21-33.

Lee Bong-Soo, Jiangang Peng, Li Guanzheng, \& He Jing. (2012). Regional Economic Disparity, Financial Disparity, and National Economic Growth: Evidence from China. Review of Development Economics, 16(2), 342-358, 2012 DOI:10.1111/j.1467-9361.2012.00666. x

Marsossetiawan. (2016). Pengembangan Finansial, Kedalaman Finansial, Akses Finansial, Kesenjangan Pendapatan Regional. Tesis. Prodi S2 Ekonomika Pembangunan Universitas Gadjah Mada. Yogyakarta.

OJK. (n.d.). Statistik Perbankan Indonesia. Retrieved September 20, 2019, from Otoritas Jasa Keuangan - OJK: https://ojk.go.id.

Zhanga Hong-Wei, Chena Wei-guo and ZhangbJie (2012). Urban-rural income disparities and development in a panel data set of China for the period from 1978 to 2006. Applied Economics, $44:$ : 2717-2728. 